\title{
Restoration of the disturbed natural hydrological regime of the fish-breeding channel Kazachy Yerik within the framework of fishery reclamation
}

\author{
Dmitry Larin ${ }^{1}$, Evgeny Mikhaylov ${ }^{2}$ and Elena Staseva, ${ }^{2, *}$ \\ ${ }^{1}$ Group of companies Zero Waste, Socialisticheskay str., 69/21, office 9a, Rostov-on-Don, 344002, \\ Russia \\ ${ }^{2}$ Don state technical University, Gagarina str.,1, Rostov-on-Don, 344003, Russia
}

\begin{abstract}
Intensive economic use of small rivers and channel water bodies leads to their pollution and siltation. The anthropogenic impact on aquatic ecosystems negatively affects the state of the fish industry, which leads to a reduction in the spawning fund, deterioration of the conditions for reproduction and survival of juveniles. Violation of the existing conditions for the habitat and reproduction of aquatic organisms leads to a decrease in the productivity of water bodies and the loss of their fishery value. The inflow from the catchment area of solid and liquid runoff containing organic matter, oil products and other impurities of anthropogenic and technogenic origin leads to irreversible entry, siltation and shallowing of small rivers and channel water bodies. The restoration of the disturbed hydrological regime of water bodies by means of reclamation works contributes to the restoration of natural spawning grounds for commercial fish species, an increase in yield and productivity.
\end{abstract}

\section{Introduction}

In order to restore rivers and reservoirs, the federal target program "Development of the water management complex of the Russian Federation for 2012-2020" was developed, approved by the decree of the Government of the Russian Federation of 19.04.2012 № 350, the order of the Federal Agency for Fisheries was adopted to conduct fishery reclamation for 2019-2021 № 87-r dated 10/29/2019.

In pursuance of clause 1 of Section III of the Water Strategy of the Russian Federation for the period up to 2020 in terms of the development of fisheries and the existing high fishery potential of water bodies in the Rostov region, research organizations of the Federal State Budgetary Scientific Institution "GosNIORKH" conducted a study of the state of water bodies in the Rostov region and developed recommendations on carrying out measures for fishery reclamation.

\footnotetext{
*Corresponding author: elena staseva@,mail.ru
} 
The recommendations define the scope of work and the timing of reclamation work for each object or its part. The rationale for the feasibility of implementing measures in the corresponding water body is presented.

\section{Materials and Methods}

In accordance with paragraph 4 of Article 44 of the Federal Law of December 20, 2004 № 166-FZ "On Fishing and Conservation of Aquatic Biological Resources", the main types of reclamation work have been determined, these are: removal of aquatic plants from a water body; dredging and (or) excavation work [1-4].

The implementation of water management measures related to the purification and restoration of small rivers and channel water bodies depends on compliance with the basic requirements for ensuring environmental safety when performing work on a water body.

Reclamation works by cleaning and deepening fish-breeding canals and reservoirs contributes to the restoration of natural spawning grounds for commercial fish species, an increase in yield and productivity. Therefore, the implementation of measures for the purification and restoration of small rivers and channel water bodies in compliance with the requirements of environmental safety is a necessary condition for the normal functioning and maintenance of a water body in proper sanitary condition [5-8].

The objectives of reclamation work are to restore the natural spawning grounds of commercial species, increase the productivity of juveniles, improve feeding conditions for juvenile fish, increase the number of commercial species and the productivity of water bodies.

The work must be performed in strict accordance with the requirements presented in the design and estimate documentation.

The scope of work includes:

- mowing of hard vegetation from the surface of the reservoir with a reed mower and moving the mown vegetation to the shore;

- dredging in lakes, channels and canals.

One of the examples of the implementation of the provisions of the Federal Target Program is the project developed by ZV Group LLC (ZeroWaste Group of Companies) "Clearing the river bed. Kazachy Erik, connecting the river. Kuban with the Big Akhtanizovsky estuary".

The design documentation was developed in pursuance of the federal target program "Development of the water management complex of the Russian Federation for 20122020", and the technical design assignment, approved by the Azov-Black Sea branch of the FGBU "Glavrybvod" [8].

The main goal of the projected measures is to restore the culvert capacity of the river. Kazachy Erik, improvement of water exchange, improvement of the state of the feeding and reproduction value of water bodies, restoration of the disturbed natural hydrological regime of the river. Kazachy Erik, improving the sanitary and fishery state of water bodies, as well as preventing the flooding of adjacent lands in the event of an emergency [9-12].

\section{Results}

The territory of the object of the Kazachy Erik branches is located in the Temryuk district of the Krasnodar. Territory of Kazachy Erik branch flows directions are west and northwest. The watercourse flows into the Akhtanizovsky estuary, which connects with the Sea of Azov with the help of the Peresypskoe branch. In geomorphological terms, the study 
area is located within the floodplain and above-floodplain terraces of the river. Kazachy Erik and r. Kuban.

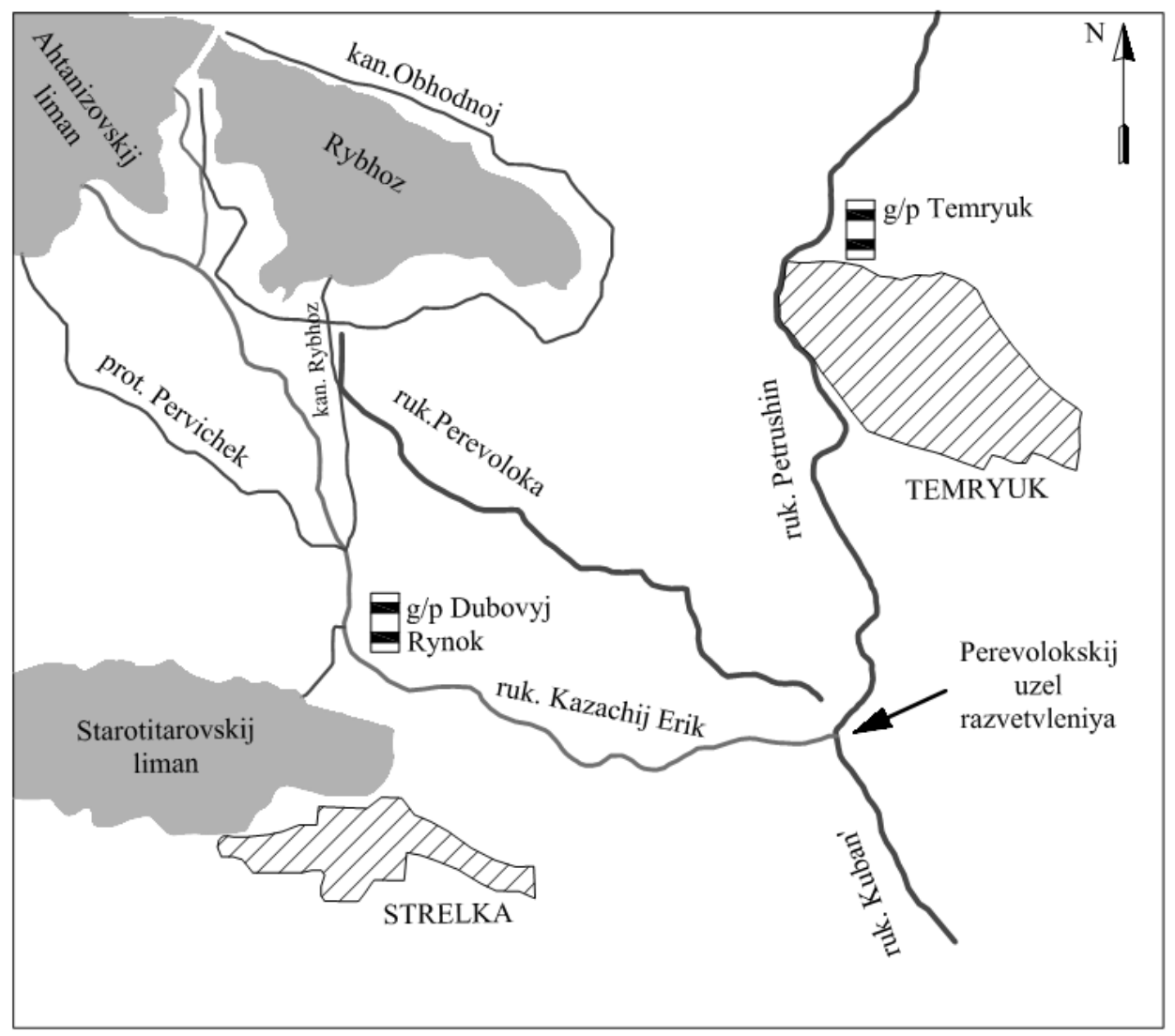

Fig. 1. Overview map of the location of the river. Kazachy Erik.

According to the materials of geodetic surveys, the total length of the Kazachy Erik branch is $19.9 \mathrm{~km}$ away. The width of the water protection zone of the Kazachy Erik branches is $100 \mathrm{~m}$. The width of coastal protection strip of Kazachy Erik branches is $50 \mathrm{~m}$.

In 1908, the Kazachy Erik received about $19.5 \%$ of the branch runoff. Kuban (at $Q=167$ $\mathrm{m}^{3} / \mathrm{s}$ ), in branch Perevoloka - 41,8\%. Remaining stock $(38,7 \%)$ went to branch Petrushin. After artificial overlapping of branches. Crossing with preliminary clearing of the channel of the Kazachy Erik, the share of Erik's runoff increased (up to 50\% in 1931).

In 1933-1937. it was (according to the data of $g / p$ ) about $45 \%$ of the branch flow. Kuban. But in the future, a noticeable tendency towards the withering away of the Kazachy Erik began to appear.

The long-term decrease in runoff into Kazachy Erik occurred gradually and with unequal intensity. The relative water content of the Kazachy Erik clearly decreased until 1977 and at a lower rate in subsequent years. Share of branch drain. Kazachy Erik with each new period became less and less. At 2001-2005 it fell to 3,1\% at $170 \mathrm{~m}^{3} / \mathrm{s}$ in branch Kuban.

One of the main tasks of the measures being developed is to maintain the optimal or natural hydrological regime of the branches. Kazachy Erik at different times of the year. The current carrying capacity of the main channel, at the water level at the level of the edge of the coast, is determined by 7 morphostoves (Table 1) [13-15]. 
Based on the materials of geodetic surveys for each design alignment, transverse profiles (morphographs) were built and the slopes of the water surface were determined. Using the table M.F. Sribny, the values of the characteristics of the roughness coefficients were selected. Then, the values of the partial areas of the water section, flow rates and partial water flows in the calculated sections were calculated. According to the calculations, the dependence curve $Q=f(H)$. The calculation results for morphostvora are presented in the table 1 .

Table 1. Calculation results for morphosts.

\begin{tabular}{|c|c|c|c|c|c|c|c|}
\hline № & PC & $\begin{array}{c}\text { Edge } \\
\text { mark. } \\
\mathbf{m}\end{array}$ & $\begin{array}{c}\text { Water } \\
\text { consum } \\
\text { ption. } \\
\mathbf{m}^{\mathbf{3} / \mathbf{s}}\end{array}$ & $\begin{array}{c}\text { Sectional } \\
\text { area. } \mathbf{~ m}^{\mathbf{2}}\end{array}$ & $\begin{array}{c}\text { Average } \\
\text { depth. } \mathbf{m}\end{array}$ & $\begin{array}{c}\text { Flow } \\
\text { velocity in } \\
\text { the section. } \\
\mathbf{m} / \mathbf{s}\end{array}$ & $\begin{array}{c}\text { The slope of } \\
\text { the water } \\
\text { surface at the } \\
\text { site }\end{array}$ \\
\hline 1 & PC 1 & 1.32 & 48.06 & 135.44 & 3.35 & 0.35 & 0.00001920 \\
\hline 2 & PC 21 & 0.97 & 38.95 & 61.81 & 2.16 & 0.63 & 0.00007600 \\
\hline 3 & PC 61 & 1.0 & 23.54 & 51.69 & 2.33 & 0.46 & 0.00005300 \\
\hline 4 & PC 85 & 0.52 & 32.62 & 97.64 & 2.36 & 0.33 & 0.00002270 \\
\hline 5 & PC 107 & 0.37 & 25.20 & 33.78 & 1.64 & 0.75 & 0.00009500 \\
\hline 6 & PC 123 & 0.37 & 18.85 & 34.24 & 1.76 & 0.55 & 0.00015300 \\
\hline 7 & PC 146 & 0.11 & 14.98 & 33.74 & 1.37 & 0.44 & 0.00008700 \\
\hline
\end{tabular}

The estimated maximum water discharge with a probability of exceeding $10 \%$ is within the embankment dams. After PC 146, the Kazachy Erik is divided into channels that flow into the Akhtanizovsky estuary. Within these limits, there is no embankment channel, and when the maximum water discharge passes the probability of exceeding $10 \%$, the adjacent territory is flooded (when the water level exceeds $0.01-0.60 \mathrm{~m}$ ).

\section{Discussion}

The main goal of the measures being developed is to restore the culvert capacity of the watercourse bed, improve water exchange, improve the state of the feeding and reproductive value of water bodies, restore the disturbed natural hydrological regime of the branch, improve the sanitary and fishery state of water bodies, and prevent flooding of adjacent lands [14-15].

Hand clearing works. Kazachy Erik envisaged:

1. Summary of reeds in the area 15,935 ha.

2. Cutting off the fertile soil layer on the sites with a layer of at least $0.2 \mathrm{~m}$.

3. Formation of temporary road, a ferry, a site for a construction base and a parking lot.

4. Arrangement of bunded areas for drying and storage of bottom soils (the formation of rollers along the perimeter of the sites $3 \mathrm{~m}$ high, $2 \mathrm{~m}$ wide along the ridge and the laying of slopes: upstream 1: 1.25 and downstream 1: 1.5).

5. Collection of driftwood (wood residues) with a self-propelled dredger using a grapple with its further loading into non-self-propelled scows, transportation by a tugboat to the place of unloading.

6. Loading and unloading firewood (wood residues) using a manipulator and transportation by dump trucks to permanent storage sites for preparing firewood.

7. Mechanized development of the bottom soil by a self-propelled dredger using a bucket with its further loading into self-unloading non-self-propelled scows and transportation by a tugboat to the unloading point (PC 106 Kazachy Erik branch).

8. Hydro-mechanized development of bottom soil with a self-propelled dredger using a cutting dredger and supply of pulp to bunded areas for drying and storage.

9. Removal of clarified water from the sites and drying of the bottom soil. 
10. Collection and transportation by a specialized organization to the solid waste landfill of production waste.

11. Dismantling of a temporary road, a crossing and sites for a construction base, a parking lot and storage of firewood (wood residues).

12. Reclamation of sites.

Carrying out activities to clear the channel of the hands. Kazachy Erik is provided in a mechanized and hydro-mechanized way using the Watermaster Classic III dredger. The dredger is self-propelled, does not require preparatory work when launching. Dredger additional equipment - cutting dredger (pulp performance $600 \mathrm{~m}^{3} / \mathrm{h}$ ) and bucket (volume $\left.0,4 \mathrm{~m}^{3}\right)$. Category of developed soils $-\mathrm{I}$.

Before the device of these sites, the reeds are mowed with tractor-based brush cutters. The cut reeds are collected and placed with the help of a tractor-based grubber-collector along the entire perimeter of the embankment dam base and used as an elastic anti-seismic pad. After that, the plant soil is cut by a bulldozer with a layer thickness of at least $20 \mathrm{~cm}$. The fertile soil layer is moved to temporary cavaliers. Next, the soil is cut with a bulldozer with a layer of $1.0 \mathrm{~m}$ to form rollers (dams) with an excavator along the perimeter of sites № 1, № 2 and № 3 with a height of $3 \mathrm{~m}$, a width of $2 \mathrm{~m}$ along the ridge and the laying of slopes: upstream 1: 1.25 and downstream $1: 1.5$.

Work on clearing the channel of the hands. Kazachy Erik are divided into two stages:

- collection of firewood (wood residues);

- removal of bottom sediments.

The first stage includes work on the collection of driftwood in the channel of the branches. Kazachy Erik with a total length of $19.97 \mathrm{~km}$ by a self-propelled dredger Watermaster Classic III with the help of additional equipment - a grab bucket.

The second stage includes work on the development of the bottom soil (loamy silt) with a self-propelled dredger Watermaster Classic III using a bucket and a cutting dredger on watercourse sections with a total length of $18,156.6 \mathrm{~m}$.

\section{Conclusions}

Clearing the channel of the Kazachy Erik branches from bottom sediments and driftwood will restore the channel's cultivation capacity, improve water exchange, the state of the feeding and reproduction value of water bodies, the sanitary and fishery state of the watercourse, and reduce the risk of negative impact of waters on adjacent territories [8-10].

Calculation of the throughput of a watercourse, after carrying out measures to clear the channel of the branches. Kazachy Erik is given in the table 2.

From this table it follows that after clearing the channel, the flow rate is passed $55,0 \mathrm{~m}^{3} / \mathrm{s}$ at the section PK0 - PK85, i.e. 58\% more than under existing conditions. At the same time, the flow rate remains within the permissible average speed for sandy soils according to table 11-7 P.G. Kiselev "Handbook of hydraulic calculations". 
Table 2. Calculation of the throughput of the watercourse, after the event for clearing the channel of the branches. Kazachy Erik.

\begin{tabular}{|c|c|c|c|c|c|c|c|}
\hline № & PC & $\begin{array}{c}\text { Edge } \\
\text { mark. } \\
\mathbf{m}\end{array}$ & $\begin{array}{c}\text { Water } \\
\text { consum } \\
\text { ption. } \\
\mathbf{m}^{\mathbf{3}} \mathbf{s}\end{array}$ & $\begin{array}{c}\text { Sectional } \\
\text { area. } \mathbf{~ m}^{2}\end{array}$ & $\begin{array}{c}\text { Average } \\
\text { depth. } \mathbf{m}\end{array}$ & $\begin{array}{c}\text { Flow } \\
\text { velocity in } \\
\text { the section. } \\
\mathbf{m} / \mathbf{s}\end{array}$ & $\begin{array}{c}\text { The slope of } \\
\text { the water } \\
\text { surface at the } \\
\text { site }\end{array}$ \\
\hline 1 & PC 1 & 1.32 & 57.76 & 146.00 & 3.43 & 0.40 & 0.0000192 \\
\hline 2 & PC 21 & 0.97 & 57.66 & 71.04 & 2.50 & 0.81 & 0.0001750 \\
\hline 3 & PC 61 & 0.77 & 56.47 & 82.50 & 2.87 & 0.68 & 0.0000730 \\
\hline 4 & PC 85 & 0.52 & 56.23 & 111.33 & 2.70 & 0.31 & 0.0000610 \\
\hline 5 & PC 107 & 0.37 & 27.67 & 40.73 & 2.30 & 0.68 & 0.0000950 \\
\hline 6 & PC 123 & 0.37 & 25.40 & 45.91 & 2.39 & 0.55 & 0.0001530 \\
\hline 7 & PC 146 & 0.11 & 20.03 & 43.93 & 1.78 & 0.46 & 0.0000870 \\
\hline
\end{tabular}

The decrease in flow rates after PC 85 is due to the distribution of the channel flow through the irrigation canals located at PC 83, PC 93 and PC 107. After PC 146 in the main channel, there is a decrease in runoff due to the distribution of the runoff part to branch № 2 .

The projected measures will have a positive impact on the restoration of the natural hydrological regime of the watercourse.

As a result of the channel cleaning works, $217482.41 \mathrm{~m}^{3}$ bottom sediments will be removed, which will increase the throughput of the main channel on the PK0-PK85 section to $55,0 \mathrm{~m}^{3} / \mathrm{s}$ or at $58 \%$ compared to the existing.

The implementation of the projected measures will generally increase the natural fish productivity, improve the ecological state and quality of water resources of the hands. Kazachy Erik, without causing damage and negative impact on the environment. The activities envisaged by the project are carried out on a scale that does not entail changes in the ecological situation of the habitat, breeding conditions, molting, wintering and stopping on the flights of waterfowl and their death. To compensate for the damage caused to aquatic biological resources in connection with the implementation of dredging works in the river bed, the project provides for the costs of compensation for damage to aquatic biological resources.

\section{References}

1. N. Serpokrylov, A. Smolyanichenko, S. Starovoitov, E3S Web of Conferences 175, 02009 (2020)

2. E.V. Vilson, L.A. Dolzhenko, E.E. Schutskaya, Materials Science Forum 931 MSF, 974-978 (2018)

3. O.A. Palacios et al., Agricultural Water Management 184, 19-27 (2017)

4. E.V. Omelchenko, E.A. Trushkova, M.V. Sidelnikov, et al., IOP Conference Series: Earth and Environmental Science Current Problems and Solutions. "Ecology and Safety in the Technosphere: Current Problems and Solutions", 012018 (2017)

5. D.A. Butko, I.S. Melnikov, I.V. Tsarevskaya, IOP Conference Series: Materials Science and Engineering 1001(1), 012056 (2020)

6. K. Khaskhoussy, B. Kahlaoui, B. Messoudi Nefzi et al., Engineering, Technology \& Applied Science Research 5(3), 805-810 (2015) http://doi.org/10.5281/zenodo.18803

7. O.A. Palacios et al., Agricultural Water Management 184, 19-27 (2017)

8. D. Larin, E. Staseva, I. Pchelnikov, IOP Conference Series: Earth and Environmental Science The conference proceedings. Far Eastern Federal University 022228 (2019) 
9. A. Sazonova, O. Kopytenkova, E. Staseva, IOP Conference Series: Materials Science and Engineering 21, Construction - The Formation of Living Environment 032039 (2018)

10. D. Butko, E. Vilson, E. Yakovleva, MATEC Web of Conferences 106, 07003 (2017)

11. S.L. Pushenko, L.E. Shvartsburg, S.A. Ryabov, N.A. Ivanova, IOP Conf. Series: Materials Science and Engineering 1001, 012092 (2020)

12. S.L. Pushenko, E.V. Staseva, M.V. Kvitkina, IOP Conf. Series: Materials Science and Engineering 1001, 012115 (2020)

13. A. Kostrov, E. Staseva, M. Molev et al., IOP Conf. Series: Materials Science and Engineering 1029, 012107 (2021) doi:10.1088/1757-899X/1029/1/012107

14. O.P. Shishova, E.E. Schutskaya, A.S. Smolyanichenko, IOP Conference Series: Materials Science and Engineering 913(4), 042046 (2020)

15. Z. Muyen, G.A. Moore, R.J. Wrigley, Agricultural Water Management 99.1, 33-41 (2011) 